\title{
Developing Children Gross Motor Skills through Combination of Explicit Instruction Model, Role Playing Model and Jump Rope Game in Kindergarten
}

Ishak $\operatorname{Sin}^{1}$, Mohammad Dani Wahyudi ${ }^{2 *}$, Eka Fauzana ${ }^{2}$

ISchool of Education and Modern Languages, Universiti Utara Malaysia, Sintok, Kedah, Malaysia

${ }^{2}$ Department of Early Childhood Education, Universitas Lambung Mangkurat, Banjarmasin, Indonesia

\begin{tabular}{l|l}
\hline \multicolumn{1}{c}{ A R T I C LE I N F O } & \multicolumn{1}{c}{ A B S T R A C T } \\
\hline $\begin{array}{l}\text { Received: 09-03-20I7 } \\
\text { Revised: 08-05-2017 }\end{array}$ & $\begin{array}{l}\text { The main purpose of this research is to develop children gross motor skill in } \\
\text { performing physical game regularly. This research applied qualitative approach with } \\
\text { classroom action research type that conducted on group B Aisyiyah Kindergarten 3I } \\
\text { of Banjarmasin explicit instruction model, role playing model and jump rope game. } \\
\text { The result of the research shows teacher's activities' improvement affecting the } \\
\text { children improvement skills in gross motor development. }\end{array}$ \\
$\begin{array}{l}\text { Keywords: } \\
\text { playing, jump rope game, } \\
\text { gross motor }\end{array}$ & $\begin{array}{l}\text { C The Authors. (2017). Journal of K6, Education, and Management, 1(1), 7-12, ISSN: 2580- } \\
\text { 2135, Published by Graduated Program of Educational Management Universitas Lambung } \\
\text { Mangkurat. This is an open access article under the open journal systems 3. }\end{array}$ \\
\cline { 2 - 2 }
\end{tabular}

*Author correspondence: Mohammad Dani Wahyudi; E-mail: mdaniwahyudi@ulm.ac.id 


\section{Introduction}

Early childhood is one of important periods in human life such Sujiono (2009) states that early age children are individuals who are undergoing development process rapidly and it is fundamental for the future.

One of the important development aspects in early childhood education programs is motor physical aspect, in which there are fine motor and gross motor skills. Physical and motor development are based on similar development pattern, namely cephalocaudal and proximodistal development. Therefore, children physical and motor development can be predicted, whether it is normal or having difficulties. Even though it is based on similar pattern, but there is a difference in the development rate between one child and another. Therefore, there is no two identical individuals, either in physical growth or in motor development.

There are various ways for children in learning motor skills, namely trial and error, imitation and training that gives different results. For this reason, the methods that children use to learn motor skills need great attention (Al-Tabany, 2015).

Normal physical development is one of determinant factors for smooth learning process, both in the field of knowledge and skills. Therefore, motor skills development is very supporting the successful of students learning. In accordance with children physical or motor development that are ready to receive skill lessons, schools need to facilitate the development of children motor functionally (Yusuf, 20I4).

The fact, on children group $B$ at Aisyiyah Kindergarten 3 I of Banjarmasin, the gross motor skills especially on the development achievements in performing physical games on regular basis have not developed yet. It is seen from development result of gross motor skill when the children performed physical game regularly at Aisyiyah Kindergarten $3 \mathrm{I}$ on group B of 15 children. This condition is contrastive with early childhood development in general, who love to move around sprightly. The reason we found in the field are as follows: (I) children factor, that is limited gross motor skills development using game because the child performed physical game such as jumping, without following the rules and instruction so they tend to move and jump at their own will, (2) teacher's factor in gross motor skills development is presenting games without stages or avoiding to perform games step by step, (3) limited time, since there are five basic development (religious and moral values, social emotional, language, cognitive, art) that need to be delivered to the children.

If gross motor skills of the children are not developed as it should be, it will affect children gross motor skills further development. Children gross motor skills development also affects to other aspects of development such as development of physical, social emotional, language competence and even to children cognitive development.

In order to help children developing their gross motor skills optimally, innovation needs to be conducted by combining explicit instruction model and role-playing model. By applying combination of explicit instruction model and role-playing model and added with jump rope game medium, it is expected that gross motor skills problems will be decrease.

This solution by using explicit instruction model is to solve the problems of the teachers who face difficulties in playing games orderly. So, with the explicit instruction model, the teacher will be easier in performing gross motor skills games in sequence or step by step. Consequently, children will master the knowledge and are also active in the learning activities. Moreover, by using role playing model can solve problems concerning the children factor, for example by providing children the opportunity to practice the roles that must be performed. For instance, in jump rope game, there will be a child who plays role as rope holder and the other as the jumper.

Gross motor movement needs coordination of the most body parts of the children. Therefore, it usually needs more power because it is performed by mass body muscles (Sujiono, 2013). The purpose of developing children gross motor skills is to help enhancing the children physical motor skill, control body movement and coordination, as well as enhancing physical skill and healthy lifestyle to support their physical growth for a 
strong, healthy, and skilled beings (Sujiono, 2006).

Every child is unique, there is no two identical children even they are twins. Every child is born with different potential; different strengths, talents, and interests. Early childhood (0-6 years old) is the golden age, in which stimulation of all development aspects plays important roles for the further development (Trianto, 20I0).

Normal physical development is one of determinant factors for smooth learning process, both in the field of knowledge and skills. Therefore, motor skills development is very supporting the successful of students learning. In accordance with children physical or motor development that are ready to receive skill lessons, schools need to facilitate the development of children motor functionally (Syamsu, 20I4).

The functions of gross motor skills development indicate a good physical health, relieve the body from tension, perform daily activities independently, do their favorite hobbies, help the children to socialize, and foster self-confidence (Ariani \& Haryanto, 2010). The gross motor skills indicators for group B children are as follows: a) Twisting and swinging arms b) Hopping in various directions with one foot off ground or two. c) Jumping from 30-40 cm height. d) Running while hopping without falling. e) Demonstrating gross motor skills such as jumping and running with many variations.

Playing time is favored by children. By playing, children will have passion to learn. Children can play while having creativity. Playing for children is not just for killing time, but as a medium for them to learn. Because playing has positive values for children development (Lestari, 2012).

The benefit of playing in general is that it has a positive impact for children development. The functions of playing for children are to help physical development, development of gross and fine motor skills, emotional and personality development, enhance cooperation with peers, reduce tension, improve the cognitive development, develop the exploration, and as a safeguard for potentially harmful actions, as well as essential for the children health.

Skipping rope, jump rope, or sapintrong (traditional jump rope) become the favorite games for children in the afternoon or after school. The jump rope game is usually involving boys and girls. The rope used for this game is rubber bands which are tied together or woven.

How to play group jumping rope: I) jump rope is quite simple game because it only jumps the rubber-woven rope at a certain height. The rule is simple, if the child can jump over the rope, then he/she will remain a jumper until the game is over, b) there are a series of height that must be accomplished in a game, that is: the rope is at the knee of the rope holder, the rope is raised to waist height, the position of the rope is at the chest of the rope holder, the position of the rope is at the ears of the holder, the position of the rope is above the head, the position of the rope is a span over the head, the position of the rope two span over the head, and the position of the rope is as high as the holders pointing finger upwards.

The tool used in the jump rope game is a rope made of rubber bands. This game needs a quite spacious place. For the safety in playing, stones or sharp objects around the yard should be removed. The number of players in jump rope game can be divided into groups according to the number of the children playing.

This rope jump game can develop gross motor skills of children. In this game, the children will learn the technique or how to jump well, how to make a good landing, measure the jump height, and so on. It will make the children grow to be deft, agile, and dynamic. Their muscles will be dense, hard, strong, and well trained. Jumping rope can also reduce obesity on children. In addition, the children's emotional will also be more controlled, that is the courage to make a higher challenged leap. This game should be played in groups, so the children will need friends/partners. Consequently, it provides them the opportunity to socialize. They can also develop empathy, taking turns, obeying the rules, etc (Mulyani, 2016).

\section{Methodology}

A good methodology should bring the researcher to achieve of the objective (Dalle, 2010; Dalle et al., 2017; Derlina et al., 2018). This classroom research used qualitative approach. Qualitative research is a research that aims to understand the phenomenon experienced by the subject under 
study such as behavior, perception, motivation, action, and others holistically and by describing in the form of words and sentences in a natural context and by utilizing various natural methods.

This research was conducted at Aisyiyah Kindergarten $3 \mathrm{I}$ of Banjarmasin. This research was planned to be performed at odd semester of academic year of 2016/2017. The subject of the research was all group B students at Aisyiyah Kindergarten $3 \mathrm{I}$ of Banjarmasin academic year of 2016/2017. The numbers of the students were I7 children consisting of I 3 girls and 4 boys. The research procedure was a series of stages from the beginning to the final. This research procedure includes stages of (I) Planning, (2) Acting, (3) Observing, and (4) Reflecting.

The data presented in this classroom action research were qualitative, that are: I) data about teacher activities in the process of learning stages in developing gross motor skills, 2) data about children activities in group $B$ at Aisyiyah Kindergarten $3 \mathrm{I}$ of Banjarmasin in developing gross motor skills, and 3) data result of children gross motor skills development of group B at Aisyiyah Kindergarten $3 \mathrm{I}$ of Banjarmasin in performing physical games regularly.

The data collection techniques are: I) teacher activities data obtained from the observation of teacher activities while delivering learning on gross motor skills in the achievement of the development by performing physical game regularly, 2) children data activities obtained from the observation during the teaching and learning process which was collected by using observational sheet assessment and children activity research sheet when activities took place, and 3) data on the development of children gross motor skills in performing physical game regularly was taken by conducting assessment after learning activity through the combination of explicit instruction model and role playing model with jump rope game in each meeting.

Data analysis is a technique analyzes the data of the research to prove the hypothesis that had been formulated. For classroom action research, the data analysis was based on the observation of learning activities and the results of this data analysis were used as a reflection for the researcher to act in the next meeting. Techniques of teacher activity analysis in observing and assessing the activities phase was starting from opening, main, and closing activities through assessment rubric for teacher activities and used scores on the observation sheet. The data about child activities in learning and the analysis of development of children gross motor skills was conducted in order to find out the percentage of the progress by calculating individual and classical development.

This Classroom Action Research was considered as successful if: I) Teacher activities in performing learning activities in terms of teaching jumping rope game was considered as good if it achieved the minimum criteria with the score of 2 I measured using the observation sheet of learning activities implementation; 2.) Children activities during the learning activities by playing jumping rope was said to be successful if every child earned the minimum criteria at least good with a score at the very least $63 \%$ categorized as active, and 3 ) Achievement results of children gross motor skills development individually reached at least three stars $\star \star \star$ with the category of Developing as Expected.

\section{Results and Discussion}

Based on the results of the research since the first meeting until the third meeting, the chart of teacher activity in developing rough motor aspects by applying rope jump game and using combination of explicit instruction model and roleplaying model.

Based on the results of data analysis as presented in the previous section of this research, it is found that teacher activity has increasing trends in implementing learning for gross motor activities by performing physical games regularly using explicit instruction model and role-playing model in jump rope game. It always increases at every meeting from Meeting I, Meeting II, to Meeting III.

Based on teacher activity chart above, first meeting is categorized as fair, meeting two obtained good category, and third meeting is in excellent category. The increasing teacher activities by each meeting is also because the teacher continues to reflect on weaknesses in the previous meeting. The teacher was performing learning while playing which is in accordance with Lestari (2012), playing time is favored by 
the children. By playing, children will have passion to learn. Children can play while having creativity. Playing for children is not just for killing the time, but as a medium for them to learn. Because playing activity have positive values on children development.

In addition, teacher also facilitates the children by providing learning media to make them easier to understand the lesson as Syamsu (20II) said, it is in accordance with children physical or motor development which is ready to receive skills lesson, then the school needs to facilitate the children motor development functionally.

In addition, the children should also be motivated by the teacher, whether it is extrinsic or intrinsic to make the children passionate to learn as Sani (2016) said, learning motivation is something that can motivate learners or individuals to learn. Without learning motivation, a student will not learn and finally he/she will not achieve success in learning. There are two types of motivation: extrinsic motivation, motivation from the outside for example giving rewards when the child managed to do something such as rewarding the stars, and intrinsic motivation is from the child himself, for instance the child learns science because he loves this subject.

In teaching children, the teacher should have good personality, be able to guide the students to be better a person and be able to help the student to solve problems as Hamalik (2013) said, the teacher is in charge to teach the students and deliver the lessons well, so that the students can understand well all the materials that has been delivered. Moreover, teacher is obliged to help children to solve problems faced by them.

Teachers should create a comfortable atmosphere for children and teachers should also be able to understand about the unique characteristics of each student, so that the learning objectives can be achieved; according to Djamarah (20II), teacher needs to know and understand the individual differences in intellectual, especially for forming groups. Children need to be divided into groups with various intelligence level. It is expected that the less intelligence child will be encouraging to be more creative, being involved with high motivation in cooperating with the partners in the group.
As the aspect I want to develop here in terms of children gross motor skills, the teacher should be able to teach the children about the balance technique in jumping but with the condition of practicing first before jumping the rope as Hasan (201I) statement's, basic skills that must be mastered by children in jump phase is a good balance, motor skills coordination and motor. Stimulating them by practicing jumping for distance can be performed by drawing circles using chalk with arranged positions. Then, ask the children to jump over the circles. Increase the difficulty level by extending the distance and using two legs, then one leg in turn.

Teacher conducting classroom action research with the purpose to enhance the learning quality, as Sanjaya (2009) statement's that enhancing learning quality can only be performed if the teacher is aware about the problems, then based on the problems the teacher designs and plans the learning programs that can improve and solve the problems, teacher then implements the program systematically and empirically.

Therefore, the teacher should support the children gross motor skills development to develop well. Models and media can be applied to support children gross motor is by using explicit instruction model and role-playing model by applying jumping rope as the medium made of woven rubber band to perform this activity. Through the model presented by teacher, the learning process can run well, and children can be directly and creatively involved, so that the learning process implemented is more effective and fun.

Children activities increased is due to the selection of the right learning model in performing and implementing physical games regularly using the jump rope game in developing the children gross motor. According to Gadner in Mulyani (2016), through playing, children are not only obtaining happiness but also developing basic development aspect. Through playing, children are also learning. Because learning for childhood is different from learning in the primary or secondary school.

According to Lestari (2012), the development of playing according to Piaget theory are as follows: sensory motor games, preoperational games with symbolic functions, games that have rules (concrete operational), and games that have rules 
and sports (formal operational). In Piaget's concept, playing gradually will have certain intention such as want to win, achieve a good result.

According to Hasan (20II), running development will affect the development of jumping, throwing, and concentration ability of the children. It requires body balance, footwork speed, precision of four-foot patterns, and motor planning.

According to Mulyani (2016), jump rope game has advantages to develop children gross motor skills, learn how to jump well, how to make a good landing, measuring jump height, reduce child obesity, control children emotions which is the courage to jump with increasing challenges, accuracy and precision, socialize, feel empathy, and obey the rules.

According to Sujiono (2006), to develop the children basic skills in terms of their physical/motor skills, kindergarten teachers should help to improve children's physical/motor skills by introducing and training children gross and fine motor movements, enhancing the ability to manage, controlling body movement and coordination, and improving the body skills and a healthy lifestyle to support strong, healthy physical growth and skilled beings.

According to Al-Tabany (2015), there are various ways for the children to learn motor skills, namely trial and error, imitate, and training that gives different results. For this reason, great attention to the methods used by the children to learn music skills is needed.

Children at 2-6 years old advance rapidly in motor skills, both gross motor skills involving big muscles like running, jumping, climbing, and fine motor skills as the coordination results of small muscles with eyes and hand like drawing, cutting, and sticking the paper.

Based on the statements above, children of 2-6 years old experience rapid growth in performing motor skills. To make children interested and feel happy during the conducted activity, the teacher should be carefully selecting the method. The method to be applied by the teacher is by conducting learning with playing.

By learning while playing, the children will be happy and excited in joining the learning activities. Before the game begins, the teacher should provide some rules that must be obeyed by the children with mutual agreement. In addition, the teacher should facilitate the activity in developing gross motor skills such as providing jump rope game. This game has a lot of advantages for early childhood development.

Children gross motor skills in jump rope game using the combination of explicit instruction model and role-playing model.

Based on the results of children gross motor development in performing physical games regularly that is rope jump game, it increases at each meeting and the result is the success development of children gross motor skills. Meeting I am initiated with begin to develop category, Meeting II with developing as expected category, and Meeting III with excellent development category.

The success of the development process of children gross motor using role playing model and explicit instruction model in performing jump rope game is carried out in fun and gradually in accordance with the ability of children (Soetjaningsih, 2012).

Role playing learning model is the way to master the learning materials by developing imagination and appreciation of the students on the materials. The intention of this learning model is to describe an event with many people involving and based on the didactic, it is better to be dramatized it rather than being told because it will become clearer and can be appreciated by the children.

Explicit instruction learning model is specifically designed to develop students' understanding about procedural and decorative knowledge that can be conveyed by using step by step pattern (Shoimin, 20I4).

This rope jump game can develop gross motor skills of children. In this game, the children will learn the technique or how to jump well, how to make a good landing, measure the jump height, and so on. It will make the children grow to be deft, agile, and dynamic. Their muscles will be dense, hard, strong, and well trained. Jumping rope can also reduce obesity on children. In addition, the children's emotional will also be more controlled, that is the courage to make a higher challenged leap. This game should be 
played in groups, so the children will need friends/partners. Consequently, it provides them the opportunity to socialize. They can also develop empathy, taking turns, obeying the rules, etc. (Mulyani, 2016).

Playing is an activity performed repeatedly and causing happiness/satisfaction for someone. According to Sujiono (2006), the role of creative games for children physical motor development is to enrich the movements. Various movements of motor sensory, hand, legs, head or other body parts involving big muscles or small muscles of children enable the children to fully develop their physical-motor skills.

In order to meet the aspects of children development, in terms of motor, cognitive, socialemotional and language as well as other aspects such as religion and morals, independence and art, it is necessary to take the following approaches: oriented to the needs of the children, learning while playing or playing while learning, creative and innovative approaches, conducive environments, using integrated learning, developing life skills, using various media and learning resources, learning that oriented to the principles of children development, and integrated simulation (Agustin, 20I2).

Based on the results of the research, there is a close correlation among the three factors studied, in which the improved activities of the teachers make the students activities is increasing and it impacts on the improvement of children development achievement.

\section{Conclussion and Recomendations}

It can be conclude that teacher activities, children activity, and children gross motor skills development when learning by doing physical games through combination of explicit instruction model and role playing model using jump rope game on children group B at Aisyiyah Kindergarten $3 \mathrm{I}$ of Banjarmasin shows improvement in which the teacher activities is at excellent criteria, children activities is at very active criteria and the development of gross motor aspects of the children achieve the expected indicator of success.

It is recommended by combining explicit instruction model and role-playing model, the teacher can use learning model/strategy to improve gross motor skills in kindergarten children. For the principal, it is expected to support the school to improve the learning process and outcomes in gross motor aspect through the playing activity. For future researchers, it is expected that this study can provide scientific insight to develop not only the gross motor skills study but also involving other aspects to be studied that may be used through playing method or other methods.

\section{Acknowledgment}

No acknowledgment

\section{References}

Agustin, U.W. (20II). Penilaian perkembangan anak usia dini. Bandung: Refika Aditama.

Al-Tabany, I.B.T. (2015). Desain pengembangan pembelajaran tematik. Jakarta: Prenadamedia Group

Ariani, N., \& Haryanto, D. (2010). Pembelajaran multimedia di sekolah. Jakarta: Prestasi Pustak

Dalle, J. (20I0). Metodologi umum penyelidikan reka bentuk bertokok penilaian dalaman dan luaran: Kajian kes sistem pendaftaran siswa Indonesia. Thesis $\mathrm{PhD}$ Universiti Utara Malaysia.

Dalle, J., Hadi, S., Baharuddin., \& Hayati, N. (2017). The Development of Interactive Multimedia Learning Pyramid and Prism for Junior High School Using Macromedia Authorware. The Turkish Online Journal of Educational Technology, November. 7I4-72I.

Derlina., Dalle, J., Hadi, S., Mutalib, A.A., \& Sumantri, C. (2018). Signaling Principles in Interactive Learning Media through Expert's Walkthrough. Turkish Online Journal of Distance Education (TOJDE). I9(4), I47-I62

Djamarah, S.B. (20II). Psikologi belajar. Jakarta: Rineka Cipta.

Hamalik, O. (2013). Proses belajar mengajar. Jakarta: Bumi Aksara

Hasan, M. (20II). Pendidikan anak usia dini. Jogjakarta: Dina Press

Lestari, S. (2012). Aktivitas cerdas pengisi kegiatan paud. Jakarta: Platinum

Mulyani, N. (2016). Super asyik permainan tradisional anak indonesia. Yogyakarta: Diva Press

Sani, R.A. (2016). Inovasi pembelajaran. Jakarta: Sinar Grafika Offset.

Sanjaya, W. (2009). Penelitian tindakan kelas. Jakarta: Pranamedia Grup 
Soetjaningsih, C.H. (2012). Perkembangan anak. Jakarta: Prenada.

Sujiono, B. (2006). Metode pengembangan fisik. Jakarta: Universitas Terbuka.

Sujiono, Y.N. (2009). Konsep dasar anak usia dini. Jakarta: Indeks.

Sujiono, Y.N. (2013). Bermain kreatif berbasis kecerdasan. Jakarta: Indeks.

Trianto.(2010). Mendesain model pembelajaran inovatif-progesif. Jakarta: Kencana.

Yusuf, S. (20I4). Perkembangan peserta didik. Jakarta: Raja Grafindo Persada 